Diterima: Februari 2016 ; Direvisi: Juni 2016; Dipublikasikan: Septembert 2016

\title{
JPEB
}

Jurnal Penelitian Ekonomi dan Bisnis, 1 (2), 2016, Hal:151 - 163

http://www.jpeb.dinus.ac.id

\section{PROFITABILITAS, LIKUIDITAS DAN NILAI PERUSAHAAN \\ (INDUSTRI PROPERTI DAN REAL ESTATE YANG LISTED DI PT. BEI PADA TAHUN 2011-2014)}

\author{
Yulita Setiawanta \\ ${ }^{1}$ Prodi Akuntansi, Fakultas Ekonomi dan Bisnis, Universitas Dian Nuswantoro \\ Jalan Nakula I Npo. 5-11, Semarang 50131, Indonesia \\ Corresponding Author: youseewhy70@gmail.com
}

Diterima: Februari 2016 ; Direvisi: Juni 2016; Dipublikasikan: Septembert 2016

\begin{abstract}
This research aims to examine as partially the effect of ROA, ROEand CR on Firm Value of real estate and property company in Indonesia stock Exchange. Independent variables used are ROA (Return On Assets), ROE (Return On Equity) and CR (Current Ratio). The total sample o $n$ t h $i$ s research obtained to 174 data oberseved. The data analyzed is secondary data obtained from Indonesia stock Exchange. The analytical method in this research uses descriptive statistic, classical assumption test, F test, hypothesis test, and coefficient of determination test. The result of this study shows that ROA and CR have no significant effect on firm value, meanwhile ROE has the effect on frim value,
\end{abstract}

Keyword: : Firm Value ; Return On Asset; Return On Equity; Current ratio.

ABSTRAK

Penelitian ini mempunyai tujuan untuk menguji pengaruh ROA, ROE dan CR secara parsial terhadap nilai perusahaan pada perseroan terbatas dibidang property dan real estate yang tercatat di Bursa Efek Indonesia. Variabel independen yang digunakan adalah ROA (Return On Asset), ROE (Return On Equity), dan CR (Current Ratio). Jumlah total sampel yang di olah adalah sebanyak 174 data obeservasi. Jenis data penelitian ini adalah data sekunder. Metode analisis dalam penelitian ini adalah dengan statistif deskriptf, Uji Asumsi Klasik, Uji F, Uji Hipotesis, dan Uji koefisien determinasi. Hasil penelitian ini menunjukkan bahwa ROA dan CR tidak memiliki pengaruh signifikan terhadap nilai perusahaan, sementara itu ROE berpengaruh terhadap Nilai Perusahaan

Kata Kunci : Nilai Perusahaan; Return On Asset; Return On Equity; Current Ratio. 


\section{PENDAHULUAN}

Luas Wilayah indonesia yang mencapai $1.910 .931,32 \mathrm{~km}^{2}$ tentunya membawa keleblihan dan anugerah tersendiri bagi bangsa Indonesia. Laut Cina Selatan, Samudra Pasifik dan Samudra Hindia merupakan wliayah laut luas yang mengelilingi negara kepulauan Indonesia. Berdampingan dengan negara-negara sekitar yang tergabung dalam persatuan ASEAN ( Association of South East Asia Nations). Kekayaan alam laut yang terbentang luas serta tambang, pertanian dan perkebunan yang didaratan, menjadikan Indonesia sebagai negara yang selalu diminati oleh banyak orang-orang asing (Darwanto 2016). Posisi Indonesia yang strategis membuat para investor baik asing maupun lokal banyak melakukan kegiatan investasi di pasar modal Indonesia yang dari tahun ke tahun mengalami peningkatan.

Pasar modal dapat dijadikan alternative sumber dana perbankan. Pada tahun 2014, investor asing dengan dananya berhasil tercatat masuk ke pasar modal Indonesia telah mencapai 33 triliun. Hal ini menunjukkan, perkembangan di pasar modal cukup baik. Pada tingkat ASEAN, Indeks Harga Saham Gabungan (IHSG) di pasar modal Indonesia masuk kedua tertinggi setelah Filipina. IHSG sudah mencapai 4.800(Yulsiati 2016). Selain itu berinvestasi di pasar modal di Indonesia cukup baik. Investasi merupakan suatu komitmen penetapan dana obyek investasi dengan harapan yang akan mendapatkan suatu keuntungan dimasa yang akan datang. Investasi merupakan bentuk saham selalu menjadi pilihan dalam berinvestasi. Saham merupakan tanda bukti bahwa kepemilikan atas aset-aset perusahaan yang menerbitkan saham. Secara umum saham dibagi ke Harga saham mencerminkan perubahan minat investor terhadap saham tersebut.

Indaktor kehidupan yang dinamis dilantai bursa tentu dapat dilihat dari pergerakan perubahan harga saham yang terjadi, semakin cepat perubahan timbul dan signifikan semakin ramai investor berinvestasi pada perusahan yang tercatat dilantai bu rsa tersebut (Nurhasanah,2011). saham yang banyak diburu dan dicari maka dapat dipastikan bahwa harga saham tersebut akan cenderung mengalami perubahan naik (mahal) mengikuti pergerakan kuantitas permintaan, otomatis nilai perusahaan yang tercermin dalam nilai saham juga akan terdorong mengalami kenaikan. Demikian pula dampaknya bagi investor mereka dalam waktu yang relatif singkat akan memperoleh nilai capital gains yang diharapkan atau nilai deviden yang menjadi target mereka untuk jangka panjang.

Keputusan membeli atau tidak, memburu saham atau tidak oleh sebagain investor dilakukan dengan mengamati informasi keuangan yang dipublikasikan oleh para emiten dan para calon investor melakukan analisis fundamental atas laporan keuangan yang terpublikasi tersebut. Sehingga pada saat mereka memutuskan untuk berinvestasi ataupun tidak dasar keputusan mereka sudah dipandang cukup kuat berdasarkan analisis fundamental tersebut.

Informasi keuangan perusahaan sebagai dasar analisis untuk pengambilan keputusan berinvestasi. Secara prinsip hal yang mudah dipahami oleh calon investor adalah jika mereka meneukan informasi keuangan yang di publikasi tersebut memberikan peryataan yang menunjukan bahwa perusahaan tersebut menunjukan posisi keuntungan atau laba yang baik atau dipandang signifikan baik yang secara nyata gamblang di laporan laba rugi atau dalam bentuk - bentuk peryataan rasio profitabilitas seperti Return On Asset (ROA) dan Return On Equity (ROE), dimana dalam penelitian-penelitian sebelumnya juga ditemukan hubungan antara profitabilitas terhadap nilai perusahaan yang diukur dengan harga saham (Sondakh, Tommy, and Mangantar 2015).

Analisis Tingkat profitabilitas perusahaan yang dihubungkan dengan perubahan harga saham biasanya adalah ROE (Retrun On Equity) dan ROA (Retrun On Asset) disamping yang lainya, sedangkan untuk tingkat likuiditas sering dipergunakan CR (Current Ratio). ROE dapat dipergunakan untuk menilai kemampuan perusahaan dalam menciptakan keuntungan nantinya dapat dinikmtai oleh para pemegang saham. Dalam perhitungannya, ROE secara konsep dapat dihitung dengan melakukan perbandingan antara nilai laba bersih dengan modal sendiri yang miliki oleh perusahaan. Dengan melihat posisi modal sendiri tentu tidak terlepas dari tingkat hutang yang dimiliki oleh perusahaan sehingga rasio ini juga dipengaruhi oleh 
besar kecilnya hutang yang dimiliki oleh perusahaan, jika proporsi hutang perusahaan semakin besar maka rasio ini juga akan mengalami peningkatan. ROA menunjukan kemampuan perusahaan menghasilkan laba dariaktiva yang dipergunakan. Sedangkan CR menunjukan kemampuan setiap unit nilai asset lancer perusahaan didalam mengkover kewajiban jangka penrusahaan dalam satu periode pelaporan keuangan. ROA, ROE dan CR yang tersaji dalam laporan keuangan banyak dipergunakan oleh para calon investor untuk melakukan kajian fundamental sebelum mereka memutuskan untuk mengambil keputusan berinvestasi dalam portofolio mereka.(Pujiyatmoko 2015).

Perusahaan sebagai organisasi komersial pada saat pendirianya tentu memiliki tujuan yang dikehendaki oleh para pemiliknya yaitu peningkatan kesejahteraan pemilik,namun dalam praktikenya banyak informasi aktifitas bisnis perusahan yang tidak dikuasai oleh pemilik tetapi dikuasai oleh menajamen. Kondisi tersebut menyebabkan terjadinya penguasaan imformasi yang tidak berimbang yang pada akhirnya menimbulkan konflik opportunis antara pemilik dengan pengelola yang kemudian dikenal dengan teori agensi yang dikemukan pertama kali oleh (Jensen and Meckling 1976). Sehingga akhirnya pemilik mengeluarkan biaya yang dipergunakan untuk mengontrol informasi yang dikuasai oleh manajemen sehingga harapan pemilik dapat terpenuhi. Pendakatan yang dilakukan adalah dengan Impression Management Approach yang pertama kali di ungkapkan oleh (Nikoskelainen and Wright 2005) daya upaya tersebut dilakukan agar nilai perusahaan yang dicerminkan dengan nilai saham dapat mengalami kenaikan dan banyak diburu oleh para investor. Nilai perusahaan dapat tergambar dari sejumlah variabel atau sinyal yang ada pada perusahan tersebut, bagi perusahaan yang memiliki kualitas baik, maka nilai yang diterima akan di bawah nilai sebenarnya, sebaliknya jika perusahaan memiliki kualitas yang buruk akan menerima nilai di atas nilai sebenarnya sebagai bagian dari dampak dari investasi yang dilakukan oleh investor khususnya investasi pada pasar modal.

Investasi di pasar modal adalah alat untuk mempertemukan mereka yang memiliki kelebihan dana dan mereka yang membutuhkan dana, dalam mendukung pertumbuhan dan stabilitas ekonomi dalam suatu organisai (Hutabarat and Flora 2015). Investor dalam melihat kinerja perusahaan tidak hanya melihat dari sudut pandang rasio hutang perusahaan saja, mereka para investor juga melihat dari rasio profitabilitas perusahaan. Untuk mengukur rasio profitabilitas perusahaan, salah satu caranya yaitu dengan menggunakan Retrun on Equity (ROE). Retrun on Equity (ROE) menurut (Hanafi dan Halim 1996). Semakin tinggi ROE menunjukan semakin tingginya tingkat pengembalian invetasi dari hasil ekuitas perusahaan dalam meraih keuntungan dari ekuitas yang dimiliki oleh perusahaan.

Penelitian harga saham juga telah banyak dilakukan penelitian-penelitian sebelumnya dari Itabillah (2011),Kms Muanmar H.S (2014),Khairani (2011),Frendy (2014) tidak dikemukan adanya konsistensi hasil penelitian yang menguji pengaruh ROA,ROI, EPS dan CR terhadap harga saham sehingga perlu diadakan penelitian lanjutan.

Penelitian mengenai pengaruh Return On Asset, Return On Equity, Earning Per Share dan Current Ratio terhadap nilai perusahaan (Harga Saham) diantaranya dilakukan Itabillah (2011) ,menyatakan bahwa ROA,ROE,EPS dan Current Ratio berpengaruh secara signifikan terhadap harga saham yang terdaftar di Bursa Efek Indonesia sedangkan penelitian Nur Aminah (2013) menghasilkan kesimpulkan bahwa ROA,ROE,DER,NPM,ROI tidak berpengaruh terhadap harga saham.

Disisi lain dengan adanya efisiensi perusahaan dalam menggunakan laba atau keuntungan perusahaan dapat menjadi sinyal positif bagi para investor, agar dapat mengakat nilai perusahaan melalui harga sahamnya. Sinyal positif tersebut didukung oleh penelitian yang dilakukan oleh Astutik (2017) yang menyatakan bahwa profitabilitas berpengaruh signifikan terhadap nilai perusahaan. Tetapi berbanding terbalik denagan penelitian yang dilakukan oleh Azmi, Andini, dan Raharjo (2016) mengatakan bahwa profitabilitas tidak 
berpengaruh terhadap nilai perusahaan pada perusahaan LQ45 di Bursa Efek Indonesia periode 2010 - 2014.

Penelitian ini memiliki tujuan menganalisis pengaruh ROA, ROE dan CR terhadap harga saham (nilai perusahaan) pada tahun pengamatan 2011 - 2014 Perusahaan yang terdaftar di PT. BEI.

\section{TINJAUAN PUSTAKA}

\section{Teori Sinyal}

Sebelum melakukan aktifitas investasi pada perusahaan yang tercatat dipasar modal, para investor tentunya juga memnperhatikan informasi - informasi yang bersifat keuangan maupun keuangan yang dianggap membawa sinyal kondisi perusahaan saat ini ataupun pridiksi di masa yang akan datang. Tentu saja secara konsep teori inyal atau Signaling theory dipandang sebagai sinyal positif ataupun negatif yang di di informasikan oleh perusahan kepada para pemangku kepentingan termasuk para calon investor. Menurut Sari dan Zahrotun (2006), konsep dalam Signaling Theory adalah bagaimana perusahan memiliki kepentingan untuk memberikan informasi yang terbaik tentang kondisi perusahaan kepada para pemangku kepentinga sejelas mungkin dan secepat mungkin. Hal ini patut diduga karena perusahaan tindak ingin terjadi asimetri infornmasi yang lebar antara misi dan tujuan perusahaan dengan informasi yang diterima oleh para pemangku kepentingan terkait dengan persepsi mereka terhadap perusahaan tersebut.

\section{Teori Agensi}

Teori Keagenan (Agency Theory) merupakan peryataan miskomunikasi tujuan antara principal (pemilik suatu usaha) dengan agen (manajemen suatu usaha). (Jensen and Meckling 1976) menyatakan bahwa pusat pertemuan kontrak (nexus of contract) yang sistematis antara pemilik (principal) dan manajer (agent). Pada dasarnya agen bersifat oportunistik, atau mementingkan kepentingannya sendiri. Pemilik perusahaan memiliki cara tersendiri untuk mengatasi masalah keagenan dengan membuat employment contract yang mengatur tentang hak dan kewajiban bagi para pengelola, namun hak yang diberikan lebih menarik sehingga mampu mereduksi kepentingan opportunis dimasa yang akan datang (Gudono 2009).

Didalam teori keagenan dinyatakan bahwa hubungan diantara keduanya didalam menjalankan aktivitas bisnis untuk mencapai tujuan yang sama tertuang dalam suatu kontrak dimana pemilik usaha memberikan pendelegasian kekuasaan berserta atribut kewenangan yang melekat dalam pendelegasian tersebut kepada agent dalam masing-masing fungsi yang ada di organiasasi (Yasin 2016). Tentu saja dari kondisi tersebut membawa dampak bahwa agent memiliki hak dan kewajiban untuk mengambil keputusan untuk mencapai target atau tujuan yang tertuang dalam kontrak tersebut untuk kemakmuran pemberi kontrak atau dalam hal ini adalah pemilik perusahaan, namun jika dalam proses pelaksaan pendelegasian tugas dan kewenangan tersebut timbul moral hzard dari agent sehingga pemberi kontrak merasa bahwa tujuan yang dia kehendaki tidak akan tercapai karena perbuatan yang dianggap menyimpang dari para agent maka bagi pemilik perusahaan hal tersebut akan mendorong atau memicu timbulnya masalah keagenan (Ismayanti dan Hanafi 2004).

\section{Laporan Keuangan}

Laporan keuangan berisikan segala informasi yang dimiliki oleh perusahan dalam format-format yang baku dan standar untuk disajikan kepada para pemangku kepentingan yang berisikan kekayaan, kewajiban, ekuitas, beban dan penghasilan perusahan dalam suatu periode pelaporan tertentu, demikian sebaiana ayang dinyatakan oleh Tendelilin (2010), . Dalam PSAK No.1, SAK (2014) Laporan keuangan yang dimaksud terdiri dari beberapa 
jenis yaitu, Laporan Laba Rugi, Laporan Perubahan Ekuitas, Laporan Posisi Keuangan ( Neraca ), Laporan Arus Kas dan Catatan Atas Laporan Keuangan.

\section{Nilai Perusahaan}

Bukti kepemilikan investor dalam sebuah perusahaan yang berbadan hukum perseroan terbatas dinyatakan dalam bentuk saham merupakan bukti kepemilikan suatu perusahaan, pemegang saham, dimana dengan kepemilikan yang berbentuk saham tersebut investir akan mendapat return investasi berupa deviden jika dimiliki dalam rentang waktu yang lebih dari 1 periode akuntansi dan capital gain (selisih antara harga jual dan harga beli) jika dimiliki dalam 1 periode akuntansi saja (Mahmud,2013). Berbicara mengenai harga saham, menurut Anaroga (2006), harga saham dibagi dalam 3 keadaan yangdapat dijelaskan sebegai berikut :

a. Harga saham nominal

Merupakan harga yang melekat secara nominal dalam setiap lembar saham

b. Harga saham perdana

Merupakan harga yang jatuh jual pada saat pertama di transaksikan dilantai bursa

c. Harga pasar saham

Merupakan harga yang tercipta pada saat penutupan transaksi dilantai bursa

Semakin tinggi harga saham, maka semaki tinggi pula nilai perusahaan dimata calon investor. Untuk mencapai firm value umumnya para pemodal menyerahkan pengelolaan kepada profesinal. Para ahli profesional diposisikan sebagai manajer ataupun komisaris independen (Nurlaila and Islahudin 2008). Nilai perusahaan dalam penelitian ini diartikan sebagai nilai pasar yang ada dipasar modal, Nurlaila dan Islahudin (2008), sebab nilai perusahaan yang dapat diberikan kemakmuran pemagang saham secara maksimum apabila harga saham perusahaan meningkat. Firm value didifinisikan harga yang tersedia dibayar oleh calon pembeli apabila company tersebut dijual. (Brigham dan Houston 2011). Peluang dalam berinvestasi dipengaruhi oleh firm value yang dibentuk dari indikator market value saham.

\section{Return On Asset (ROA)}

Menurut Kasmir (2012) Return On Asset adalah rasio yang menunjukkan hasil (return) atau pendapatan yang digerakan dari aktiva yang dimiliki oleh perusahaan dalam satu rentang periode akuntansi. Efektifitas pengelolaan manajemen aset juga dapat dilihat dari struktur nilai yang tersaji dalam laporan keuangan yang terpublikasikan dlam bentuk peryataan rasio keuangan ROA didalam hubungan kemampuan perusahaan untu kmendatangkan pendapatan (Mardiyanto, 2009) menyatakan bahwa Return On Asset merupakan rasio yang menghubungkan keuntungan yang diperoleh atas optimalisasi penggunaan asset yang dimiliki oleh perusahaan

\section{Return On Equity (ROE)}

Tingkat pengembalian investasi para pemegang saham dapat diukur dengan menggunakan rasio keuangan Return on Equity atau ROE. Menurut Harahap (2007) ROE memberikan informasi bahwa investor akan menerima tingkat pengembalian investasi atas efektifitas ekuitas yang dijalankan oleh menajemen perusahaan. Semakin tinggi tingkat Return On Equity (ROE) yang di informasikan perisahaan kepada para calon investor maka semakin tinggi pula harga saham yang mungkin saja terbentuk pada setiap sesi penutupan transaksi dilantai bursa setiap harinya.

\section{Current Ratio (CR)}

Kasmir (2014) menyatakan Current Ratio (CR) atau dalam bahasa Indonesia rasio lancar merupakan rasio yang dipergunakan untuk menunjukan seberapa mampu perusahan 
melakukan pelunasan atas semua kewajiban jangka pendek yang dilporkan dalam lporan keuangan. Jika diketahui nilai rasio lancar suatu perusahaan pada titik rendaj maka informasi tersbeut memiliki arti bahwa perusahaan sedang dilanda masalah likuiditas didalam melaksanakan kewajiban jangka pendeknya, meskipun tingginya nilai rasio lancar bisa saja disebabkan oleh informasi atas nilai piutang yang tidak ditagih atau persediaan yang tidak terjual, dan tentu saja informasi yang dihasilkan dari rasio lancar ini tidak dapat disimpulkan bahwa perusahaan mmepunyai kemampuan membayar kewajiaban jangka pendeknya (Prastowo dan Juliaty,2012). Dapat dikatakan juga bahwa jika jumlah kewajiban jangka pendek yang dilaporkan perusahan dalam laporan keuangan jauh lebih besar daripada jumlah aktiva lancar yang dimiliki, maka dapat dikatakan bahwa posisi perusahaan pada saat tersebut dalam keadan tidak memiliki kemampuan untuk dengan segara memenuhi kewajiban jangka pendekanya atau tingkat solvabilitasnya rendah.

\section{Hioptesis}

Peryataan yang menunjukan hubungan dua variabel atau lebih yang memiliki keterikan secara konsep atau teoritias yang haru dilakukan pengujian secara empiris disebut dengan hipotesis ( Indriantoro dan Supomo,2014). Pemikiran hipotesis merupakan proses taksiran (pengkalibrasian) terhadap parameter-parameter berasal dari data primer maupun sekunder yang mempengaruhi hasil atau hubungan yang logis antar variabel-variabel yang digunakan (proposisi) yang dapat di uji dengan pendekatan secara matematis (Erlina 2008).

Dalam penelitian ini hipotesis yang diajukan adalah sebagai berikut :

$\mathrm{H} 1$ : Return On Asset berpengaruh terhadap Nilai perusahaan

$\mathrm{H} 2$ : Return On Equity berpengaruh terhadap Nilai perusahaan

$\mathrm{H} 3$ : Current Ratio berpengaruh terhadap Nilai perusahaan

\section{Populasi dan Sampel}

Populasi dalam penelitian ini adalah seluruh perusahaan yang bergerak dibidang property atau real estate yang listing di PT. BEI periode pengamatan tahun 2011-2014. Sampel yang dipergunakan adalah dengan (judgement/purposive sampling), yaitu suatu tipe pemilihan sampel yang dilakuka dengan tidak secara acak, informasi yang dipergunakan dengan menggunakan pertimbangan atau kriteria tertentu dan umumnya sesuai dengan tujuan atau masalah yang ada dalam penelitian tersebut (Indriantoro dan Supomo,2002). Kriteria yang diinginkan sebagai sampel adalah perusahaan yang listing secara berturut-turut selama tahun pengamatan berdasarkan data yang terinformasikan dari ICMD, dengan menerbitkan laporan keuangan tahunan serta membukukan laba positip selama periode pengamatan. Berdasarkan kriteria tersebut diperoleh 174 data obervasi.

\section{METODE PENELITIAN}

Metode yang dipergunakan dalam penelitian ini adalah penelitian diskriptif kuantitatif. Jenis data yang dipergunakan adalah data sekunder yang diperoleh dari ICMD dan Annual Report . Variabel penelitian ini adalah variabel independent (variabel bebas) yakni ROA, ROI dan CR sedangan kan variabel dependent nya adalah Nilai Perusahaan (Harga Saham). Metode pengumpulan data melalui dokumentasi atas sumber-sumber data yang tersedia di ICMD dan Annual Report perusahaan sampel pada periode pengamatan.

\section{Teknik Analisis Data}

Pendekatan kuantitatif dilakukan didalam penelitian ini. Secara definisi pedekatan kuantitatif merupakan analisa data yang berwujud angka-angka dan mempergunakan perhitungan secara statistik untuk menjawab hipotesis yang diajukan. Penyajian dalam 
bentuk tabel, kurva atau grafik atas analisis ini menjadi hal yang utama dan dominan untuk menjelaskan hasil pengolahan data yang berhasil di identifikasi dengan baik dalam penelitian ini agar dapat ditarik suatu kesimpulan (ghozali, 2014). Alat bantu yang digunakan adalah aplikasi SPSS (Statistical Package for Social Science). Dengan bantuan alat ini tahapan yang dilakukan adalah dengan melakukan pengolahan data yang berhasil di observasi untuk mencari statistik diskriftifnya kemudian melakukan pengujian kualitas data dengan asumsi klasik, melakukan pengujian model penelitian, menguji hipotesis dan terakhir menampilkan nilai koefisien deteminan atas data penelitian ini.

\section{HASIL DAN PEMBAHASAN Analisis Deskriptif}

Secara umum analisis deskriptif memberikan gambaran atau deskripsi suatu data yang dilihat dari jumlah sampel $(\mathrm{N})$, nilai maksimum,nilai minimum, nilai rata-rata (mean), dan standar deviasi. Sampel penelitian ini sebanyak 174 perusahaan rea estate dan property dalam kurun waktu 4 tahun. Berikut ini adalah hasil analisis deskriptif dari rasio Return On Asset,Return On Equity, Current Ratio dan Harga Saham

\section{Tabel 1. Statistik Diskriftif}

\begin{tabular}{cccc}
\hline Variabel & Mean & Std Dev & N \\
\hline Log Harga Saham & 6,1533 & 1,15209 & 174 \\
ROA & 6,806149 & 5,5196347 & 174 \\
ROE & 11,684058 & 9,7941252 & 174 \\
CR & 2,2522874 & 1,9336891 & 174 \\
\hline
\end{tabular}

Dari data tabel 1 dapat dinyatakan bahwa nilai standar deviasi semua variabel yang dipergunakan dalam penelitian ini berada pada posisi nilai yang lebih rendah dari nilai ratarata setiap variabel dalam penelitin ini. Hal ini menunjukan bahwa data dalam penelitian ini tidak terdapat terdapat perbedaan yng tinggi antara data yang satu dengan data yang lain.

\section{Uji Kualitas Data (Asumsi Klasik)}

Uji kualitas data pada penelitian ini menggunakan uji asumsi klasik. Dari hasil uji asumsi klasik yang pertama yaitu, uji normalitas data dengan menggunakan tabel one-sampel kolmogorov smirnov diperoleh nilai sebesar Asymp. Sig. (2-tailed) $=0,834$. Dari nilai tersebut karena lebih besar dari 0,005 maka dapat disimpulkan data penelitian yang diobservasi terdistribusi secara normal. Model regresi yan baik seharusnya tidak terjadi suatu korelasi diantara variabel-variabel bebsanya. Jika variabel bebas saling berkorelasi maka variabel-variabel ini tidak orthogonal. Cara mendeteksi ada tidaknya multikoliniearitas dapat dilihat dalam model regresi dengan melihat tolerance dan lawannya yaitu VIF, yaitu Jika nilai tolerance $\geq 0,1$ atau jik VIF $\leq 10$, maka tidak terdapat multikoliniritas dalam model regresi. Jika Jika nilai tolerance $\leq 0,1$ atau jik $\mathrm{VIF} \geq 10$, maka terdapat multikoliniritas dalam model regresi. Berikut tabel multikoliniearitas :

Tabel 2. Uji Multikoliniritas

\begin{tabular}{ccc}
\hline Model & Tolerance & VIF \\
\hline ROA &, 209 & 4,784 \\
ROE &, 207 & 4,827 \\
CR &, 942 & 1,062 \\
\hline
\end{tabular}


Berdasarkan tabel 2 tersebut diatas maka semua posisi nilai tolerance $\geq 0,1$ atau jika $\mathrm{VIF} \leq 10$, maka tidak terdapat multikoliniritas dalam model regresi pada penelitian ini.

Uji autokorelasi bertujuan untuk menguji apakah dalam model regresi linier terdapat korelasi antara kesalahan pengganggu pada periode $\mathrm{t}$ dengan kesalahan pada periode $\mathrm{t}-1$ (Ghozali,2011). Dengan menggunakan tabel model summary jika nilai durbin-watson berada pada nilai diantara 1 dan 3 maka dapat dikatakan tidak terjadi autokolerasi dalam data penelitian ini. Berdasarkan hasil pengolahan data diketahui nilai Durbin_Watsonya adalah sebesar : 2,129 maka dapat dikatakan tidak terjadi autokorelasi.

Uji Heterokedastisitas menguji apakah dalam model regresi terjadi ketidak bersamaan variance dari residual satu pengamatan ke pengamatan yang lain.

Tabel 3. Uji Heterokedastisitas

\begin{tabular}{ccll}
\hline Model & Beta & T & Sig \\
\hline ROA &, 093 &, 564 &, 574 \\
ROE &, 073 &, 437 &, 663 \\
CR &, 043 &, 557 &, 578 \\
\hline
\end{tabular}

diperoleh hasil bahwa semua nilai signifikansi semua diatas 0,05 yang berarti bahwa tidak terdapat gangguan heteroskedastisitas pada setiap variabel independennya.

\section{Uji Model}

Dengan menggunakan asil uji F/ANOVA dalam penelitian ini, maka dapat dikatakan jika tingkat signifikan dibawah dari 0,05 maka model dalam penelitian dapat dikatakan FIT atau bagus, berikut tabel uji F/ANOVA dibawah ini :

Tabel 4. Uji F/ANOVA

\begin{tabular}{cccc}
\hline Model & $\begin{array}{c}\text { Mean } \\
\text { Squrae }\end{array}$ & F & Sig \\
\hline Regression & 20,173 & 20,280 &, $000^{\mathrm{b}}$
\end{tabular}

Berdasarkan tabel 4 daitas maka dapat dikatakan model regresi penelitian ini adalah FIT atau Bagus.

\section{Uji Hipotesis}

Sebelum nemyatakan apakah hipotesis yang kita ajukan diterima atau ditolak maka, hasil pengolahan data dengan aplikas SPSS ini pada tabel Coefficient akan terlihat bentuk peryataan yang disajikan dalam beberapa kolom, penyajian informasi dalam kolom-kolom tersebut akan disampaikan pada tabel 5 dibawah ini :

\section{Tabel 5. Coefficients ${ }^{\mathrm{a}}$}

\begin{tabular}{cccc}
\hline Model & Beta & T & Sig \\
\hline Constant & 5,582 & 36,436 &, 000 \\
ROA &,- 002 &,- 054 &, 957 \\
ROE &, 059 & 3,493 &, 001 \\
CR &,- 050 & $-1,234$ &, 219 \\
\hline
\end{tabular}


Yulita Setiawanta : Profitabilitas, Likuiditas Dan Nilai Perusahaan (Industri Properti Dan Real Estate Yang Listed Di PT.BEI Pada Tahun 2011 - 2014)

Berdasarkan tabel 5. Daiatas maka didapatkan model persamaan regresi akhir sebagai berikut :

$$
\mathrm{Y}=5,582-0,002 \mathrm{ROA}+0,059 \mathrm{ROE}-0,050 \mathrm{CR}
$$

Dengan demikian untuk peryataan jawaban hipotesis yang dibangun dapat dikatakan bahwa :

H1 : Return On Asset berpengaruh terhadap Nilai perusahaan

Nilai signifikansi ROA sebesar 0,957>0,05 dapat disimpulkan bahwa variabel ROA tidak berpengaruh terhadap Nilai Perusahaan. Dengan demikian hipotesis pertama yang menyatakan bahwa ROA berpengaruh terhadap Nilai Perusahaan tidak terbukti (H1 ditolak)

$\mathrm{H} 2$ : Return On Equity berpengaruh terhadap Nilai perusahaan

Nilai signifikansi ROE sebesar 0,001 < 0,05 dapat disimpulkan bahwa variabel ROE berpengaruh terhadap Nilai Perusahaan. Dengan demikian hipotesis kedua yang menyatakan bahwa ROE berpengaruh terhadap Nilai Perusahaan terbukti (H2 diterima)

H3 : Current Ratio berpengaruh terhadap Nilai perusahaan

Nilai signifikansi CR sebesar 0,219 > 0,05 dapat disimpulkan bahwa variabel CR tidak berpengaruh terhadap Nilai Perusahaan. Dengan demikian hipotesis ketiga yang menyatakan bahwa CR berpengaruh terhadap Nilai Perusahaan tidak terbukti (H1 ditolak)

\section{Koefisien Determinan}

Menurut Ghozali (2011) uji koefisiensi determinasi bertujuan untuk mengukur seberapa jauh kemampuan model dalam menjelaskan variasi variabel terikatnya atau independen. Nilai $\mathrm{R}^{2}$ terletak antara 0 dan 1 atau $0 \leq \mathrm{R}^{2} \leq 1$. Nilai koefisien determinasi ditunjukkan dengan nilai adjusted $R$ square dan didalam penelitian ini diperoleh nilai adjusted $R$ square sebesar 0,251, maka dapat diartikan bahwa variabel independen (return on asset, return on equity, current ratio) dapat menjelaskan variabel dependen (Nilai Perusahaan) sebesar $25,10 \%$ sedangkan sisanya diterangkan oleh faktor lain yang tidak diamati dalam penenlitian ini

\section{HASIL DAN PEMBAHASAN}

\section{Return On Assets (ROA) Berpengaruh terhadap Harga Saham.}

Pengujian secara parsial ROA tidak berpengaruh terhadap Nilai Perusahaan. Karakteristik data penelitian menunjukan kecenderungan yang sama dengan hasil penelitian , dalam artian jika nilai ROA semakin meningkat justru Nilai Perusahaan (Harga saham) mengalami penurunan, Hal ini dibuktikan dengan data sebafai berikut :

Tabel 6. Data Sampel ROA dan Nilai Perusahaan

\begin{tabular}{ccc}
\hline Sampel & ROA & $\begin{array}{c}\text { Nilai } \\
\text { Perusahaan }\end{array}$ \\
\hline $\begin{array}{c}\text { Pikko Land } \\
\text { Development Tbk } \\
\text { Danayasa Arthatama } \\
\text { Tbk. }\end{array}$ & 16,87 & 463.00 \\
\hline
\end{tabular}

PT. Pikko Land Develeopment, Tbk yang memiliki ROA sebesar 16,67 diatas nilai ROA rata2 industri (sampel) sebesar 10,41 namun justru memiliki Nilai Perusahaan sebesar 463 yang lebih rendah dari nilai perusahaan rata-rata industri (sampel) sebesar 1.956.Demikian juga nilai ROA PT. Danayasa Arthatma, Tbk sebesar 2,36 atau lebih rendah 
dari nilai ROA rara-rata industry perusahaan sampel sebesar 10,41 namun memiliki nilai perusahan sebesar 2.000 lebih tinggi dari nilai perusahaan rata-rata industry (sampel) sebesar 1.956. Data tersebut patut diduga memberikan kontribusi tidak diterimanya hipotesis yang pertama ini.

Berdasarkan teori sinyal, setiap informasi yang diungkapkan dan yang diberikan akan mempengaruhi Nilai Perusahaan pada pasar saham, namun dalam kasus perusahan sampel ini, informasi ROA yang disajikan dalam laporan keuangan tahunan tidak direspon dengan baik oleh para investor ketika mereka mempertimbangkan dalam mengambil keputusan berinvestasi, hal ini sesuai dengan penjelasan dan contoh kasus pada kedua perusahan tersebut diatas.

\section{Return On Equity (ROE) Berpengaruh Terhadap Harga Saham.}

Pengujian secara parsial ROE berpengaruh terhadap Nilai Perusahan ( harga saham). Karakteristik data penelitian menunjukan kecenderungan yang sama dengan hasil penelitian , dalam artian jika nilai ROE semakin meningkat maka Nilai Perusahaan (Harga saham) juga mengalami peningkatan Hal ini dibuktikan dengan data sebagai berikut :

Tabel 7. Data Sampel ROE dan Nilai Perusahaan

\begin{tabular}{|c|c|c|}
\hline Sampel & ROE & $\begin{array}{l}\text { Nilai } \\
\text { Perusahaan }\end{array}$ \\
\hline $\begin{array}{l}\text { Metropolitan } \\
\text { Kencana, Tbk. } \\
\text { Ristia Bintang }\end{array}$ & 20,24 & 15.300 \\
\hline $\begin{array}{c}\text { Mahkota Sejati } \\
\text { Tbk }\end{array}$ & 3,28 & 88.00 \\
\hline
\end{tabular}

Hasil penelitian yang menunjukan adanya pengaruh ROE terhadap Nilai Perusahaan pada penelitian ini patut diduga terkontribusi oleh karakteristik data sampel penelitian yang mendukung konsep atau teori yang dibangun oleh peneliti. Sebagai contoh Nilai ROE PT. Metropolitan Kencana Tbk pada nilai sebesar 20,24 atau lebih tinggi dari pada nilai ROE rata-rata inudtri perusahaan sampel pada tahun pengamatan yaitu sebesar 8,68 dan memiliki nilai perusahan sebesar 15.300 diatas nilai rata-rata industri atas nilai perusahaan pada perusahaan sampel pada tahun pengamatan sebesar 1.956,03 atau data pada Ristia Bintang Mahkota Sejati, Tbk yang memiliki nilai ROE sebesar 3,28 atau jauh lebih rendah dari nilai ROE rata-rata industri sebesar 8,68, namun memiliki nilai perusahaan sebesar 88,00 atau jauh lebih rendah dari nilai perusahaan atas rata-rata industri perusahan sampel yaitu sebesar $1.956,03$.

Hasil penelitian ini selaras dengan teori sinyal yang dibangun dimana sinyal yang diberikan oleh perusahan melalui data-data fundamental yang berada dalam laporan keuangan yang dipublikasikan akan direkasi oleh investor abik informasi positip dengan reaksi positip seperti yang terjadi pada contoh perusahaan PT.Metropolitan Kencana, Tbk. Demikian juga sinyal negatif yang di informasikan oleh perusahan juga akan ditangkap secara negatif oleh para investor hal tersebut seperti contoh data yang didapat dari informasi keuangan PT. Ristia Bintang Mahkota Sejati, Tbk yang memiliki nilai ROE rendah dan juga memiliki nilai perusahaan (harga saham) yang rendah pula.

\section{Current Ratio (CR) Berpengaruh Terhadap Nilai Perusahaan (Harga Saham.)}

Pengujian secara parsial CR tidak berpengaruh terhadap harga saham, berdasarkan kecendurungan data dapat dijelaskan bahwa apabila CR semakin meningkat, maka harga 
saham akan meningkat, sebaliknya apabila CR semakin rendah, maka harga saham akan turun, meskipun kecenderungan tersebut tidak terbukti signbifikan pada hasil penelitian ini. Hasil ini patut diduga terkontribusi dengan karakteristik data sampel yang dapat diambil contoh sebagai berikut :

Tabel 8. Data Sampel CR dan Nilai Perusahaan

\begin{tabular}{ccc}
\hline Sampel & CR & Nilai \\
\hline Perusahaan \\
\hline $\begin{array}{c}\text { Metropolitan } \\
\text { Kencana, Tbk }\end{array}$ & 0,64 & 15.300 \\
$\begin{array}{c}\text { Lippo Karawaci, } \\
\text { Tbk }\end{array}$ & 5,23 & 1.020 \\
\hline
\end{tabular}

Sebagai contoh Nilai CR PT. Metropolitan Kencana Tbk pada nilai sebesar 0,64 atau lebih rendah dari pada nilai CR rata-rata inudtri perusahaan sampel pada tahun pengamatan yaitu sebesar 3,0 dan memiliki nilai perusahan sebesar 15.300 diatas nilai rata-rata industri atas nilai perusahaan pada perusahaan sampel pada tahun pengamatan sebesar 1.956,03 atau data pada Lippo Karawaci, Tbk yang memiliki nilai CR sebesar 5,23 atau jauh lebih tinggi dari nilai CR rata-rata industri sebesar 3,0 namun memiliki nilai perusahaan sebesar 1.020 atau jauh lebih rendah dari nilai perusahaan atas rata-rata industri perusahan sampel yaitu sebesar 1.956,03.

Hasil penelitian ini tidak selaras dengan teori sinyal yang dibangun dimana sinyal yang diberikan oleh perusahan melalui data-data fundamental yang berada dalam laporan keuangan yang dipublikasikan tidak direaksi oleh investor atas informasi positip dengan reaksi tidak positip seperti yang terjadi pada contoh perusahaan PT.Metropolitan Kencana, Tbk. Demikian juga sinyal negatif yang di informasikan oleh perusahan juga akan ditangkap tidak secara negatif oleh para investor hal tersebut seperti contoh data yang didapat dari informasi keuangan Lippo Karawaci, Tbk yang memiliki nilai CR tinggi namun memiliki nilai perusahaan (harga saham) yang rendah pula.

\section{SIMPULAN}

Kesimpulan yang bisa diambil dalam penelitian ini adalah bahwa hanya variabel ROE saja yang memiliki pengaruh signifikan terhadap nilai perusahaan (harga saham) sedangkan dua variabel lainya yaitu, ROA dan CR tidak memiliki hubungan secara sginifkan. Hal ini yang mendorong saran kepada calon investor dimasa yang akan datang jika ingin berinvestasi pada perusahaan sampel dalam penelitian ini dan return atau deviden atas saham memjadi pertimbangan utama investasi serta calon investor mempergunakan informasi fundamental yang ada dalam laporan keuangan yang dipublikasikan maka calon investor diharapkan dapat melihat nilai atau tren dari ROE nya jika tren nya positip maka patut diduga bahwa nilai perusahaannya juga akan mengalami pertumbuhan yang positip. saran yang lain adalah hendaknya peneliti yang akan datang mencari variebel pemoderasi hubungan antara ROA, ROE dan CR terhadap Nilai Perusahaan.

\section{DAFTAR PUSTAKA}

Aminah, Nur. 2016. Pengaruh Deviden Per Share, Return on Equity, Net Profit Margin, Return On Investment dan Return On Asset Terhadap Harga Saham Pada Perusahaan Real Estate dan Property yang Terdaftar di Bursa Efek Indonesia periode tahun 20112013. Journal Of Accounting, Volume 2 no.2

Anoraga, Pandji dan Piji Pakarti. 2003. Buku Pintar Pasar Modal Indonesia, Jakarta: Mediasoft Indonesia. 
Astutik, Dwi. 2017. Pengaruh Aktivitas Rasio Keuangan Terhadap Nilai Perusahaan (Studi Pada Industri Manufaktur). Jurnal STIE SEMARANG 9(1):32-49.

Azmi, Muchamad, Rita Andini, and Kharis Raharjo. 2016. Analisis Pengaruh Net Profit Margin (NPM), Return On Assets (ROA) Dan Current Ratio (CR) Terhadap Harga Saham Emiten LQ45 Yang Terdaftar Di Bursa Efek Indonesia Pada Tahun 2010-2014. Journal Of Accounting 2(2):1-10.

Brigham, dan Huston 2006. Dasar - dasar pembelanjaan perusahaan edisi 4 BPFEYogyakarta.

Darwanto, Eka Widayat Julianto; 2016. Analisis Rantai Nilai (Value Chain) Jagung Di Kecamatan Toroh Kabupaten Grobogan. Jurnal Penelitian Ekonomi Dan Bisnis 1(1).

Gudono. 2009. Teori Organisasi. 2nd ed. Yogyakarta: BPFE Yogyakarta. Retrieved (https://teorionline.wordpress.com/2012/02/20/referensi-buku-teori-organisasi-olehgudono-phd/).

Ghozali, Imam. 2011. Aplikasi Analisis Multivariate dengan program IBM SPSS21 Update PLS Regresi. Badan Penerbit Universitas Diponegoro, Semarang

Hutabarat, Francis M. and Janet Flora. 2015. Exploring Factors Affecting Stock Price of Indonesia State Owned Bank Listed at Indonesia Stock Exchange. Academic Research International 6(May):42-52.

Http://www.idx.co.id diakses 4 November 2016

Ikatan Akuntan Indonesia. 2014. Standar Akuntansi Keuangan. PSAK No.1. Cetakan Pertama. Buku Satu. Penerbit Salemba Empat. Jakarta.

Itabillah, Amaliah. Pengaruh $C R, Q R, N P M, R O A, E P S, R O E, D E R$ dan PBV Terhadap Harga Saham Perusahaan Property dan Real Estate yang Terdaftar di BEI.

Jensen, M. C. and W. H. Meckling. 1976. Theory of the Firm: Managerial Behavior, Agency Costs and Ownership Structure. Journal of Financial Economics 3(4):305-60.

Kasmir. 2012. Analisis Laporan Keuangan, PT. Raja Grafindo Persada, Jakarta KMS.Muanmar H.S. Pengaruh Earning Per Share, Return On Equity, Debt To Equity Ratio Terhadap Harga Saham Perusahaan Property dan Real Estate di Bursa Efek Indonesia Tahun 2010-2014.

Khairani, Purnamasari. Pengaruh Current Ratio (CR), Debt To Equity Ratio (DER), Return On Equity (ROE), Price Earning Ratio (PER), dan Earning Per Share (EPS)Terhadap Return Saham Pada Perusahaan Property And Real Estate Yang Terdaftar Di Bursa Efek Indonesia tahun 2009-2011.Jom FEKON, Vol 1 No.2, Oktober 2014

Mahmud M. Hanafi, M.B.A : Manajemen Keuangan Edisi I 2013 BPFE- Yogyakarta

Mardiyanto, H. 2009. Intisari manajemen Keuangan. Jakarta : PT.Gramedia Widiasarana Indonesia (Grasindo).

Nikoskelainen, Erkki and Mike Wright. 2005. The Impact of Corporate Governance Mechanisms on Value Increase in Leveraged Buyouts. 1-42.

Nurlaila, Rika and Islahudin. 2008. Pengaruh Corporate Social Responsibility Terhadap Nilai Perusahaan Dengan Prosentase Kepemilikan Manajemen Sebagai Variabel Moderating.

Nurhasanah, Rahmadi. 2011. Pengaruh Return On Assets (ROA), Return On Equity (ROE), Dan Earning Per Share (EPS) Terhadap Harga Saham (Survey Pada Perusahaan LQ45 yang terdaftar di Bursa Efek Indonesia Periode 2007-2011) Journal Akuntansi, Fakultas Ekonomi, Universitas Wiyatama. Bandung.

Pujiyatmoko, Yohanes. 2015. Pengaruh Return On Asset, Return On Equity, Earning Per Share, Dan Economic Value Added Terhadap Harga Saham Perusahaan Property Dan Real Estate Yohanes. Gunadarma University.

Sari, dan Zuhrotun, Keinformatifan Laba Di Pasar Obligasi Dan Saham : Uji Liquidation Option. Simposium Nasional Akuntansi di Padang. 2006

Sondakh, Frendy, Parengkuan Tommy, and Marjam Mangantar. 2015. Current Ratio, Debt to 
Yulita Setiawanta : Profitabilitas, Likuiditas Dan Nilai Perusahaan (Industri Properti Dan Real Estate Yang Listed Di PT.BEI Pada Tahun 2011 - 2014)

Equity Ratio, Return on Asset, Return on Equity Pengaruhnya Terhadap Harga Saham Pada Indeks LQ45 Di Bei Periode 2010-2014. Emba 3(2):749-56.

Tandelilin, E. . 2010. Portofolio dan Investasi. Edisi Pertama. Yogyakarta ; Kanisius

Yulsiati, Henny. 2016. Pengaruh Earning Per Share, Return On Equity Dan Debt To Equity Ratio Terhadap Harga Saham Dalam Jakarta Islamic Index (JII) Yang Terdaftar Di Bursa Efek Indonesia (BEI) Periode 2010-2011. Jurnal Adminika Volume 2(1):104-27. 